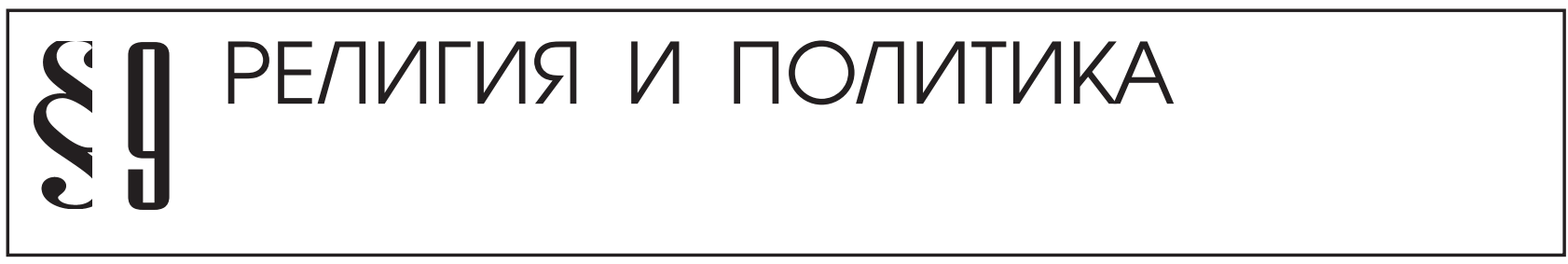

Александров А.П., Габдулхаков Р.Б.

\title{
ПРАВОВОЕ ПОЛОЖЕНИЕ РЕЛИГИОЗНЫХ ОРГАНИЗАЦИЙ В БАШКИРИИ В 30-Е ГГ. ХХ ВЕКА (НА ПРИМЕРЕ ЕВАНГЕЛЬСКИХ ХРИСТИАН И БАПТИСТОВ)
}

Аннотация: В статье рассматривается правовое положение общин евангельских христиан и баптистов Башкирии в период господства тоталитаризма в СССР. Описываются методы борьбы с иерквями: ограничение деятельности, снятие с регистрации, антирелигиозная пропаганда, увеличение налогового бремени, аресты священников и т.д. Итогом такой политики стало полное прекращение легальной деятельности иерквей к кониу 30-х годов. Период нэпа можно считать периодом временного равновесия сил, когда власти ещуе были вынуждены хотя бы внешне считаться с фактом религиозности населения СССР. К 1928 г. это шаткое равновесие заканчивается и начинается широкомасштабное наступление на веру и верующих. Страна приступает к осуществлению грандиозных планов сочиалистического строчтельства. В области внутренней политики все было нацелено на раскрестьянивание деревни и слом не только традиционного хозяйственного уклада, но и образа жизни, мышления, крестьянской религиозной идеологии. Религиозная идеология составляла серьезную конкуренцию насаждаемой новой вере - коммунизму.Таким образом, период с 1929 по 1943 г. был временем самого активного репрессивного воздействия на общины евангельских христиан и баптистов Башкирии. Правительство проводило политику уничтожения общчин верующчих, которые были поставлены в крайне неблагоприятные правовые условия. Итогом политики стало прекрашение легальной деятельности всех общзин верующих и сведение их численности до минимума. Начатый процесс приостановила только начавшаяся Великая Отечественная война.

Review: The article is devoted to the legal status of communities of Evangelical Christians and Baptists in Bashkiria during the period of the totalitarianism domination in the USSR. The author describes methods used by the government to fight against churches such as: restrictions of activities, de-registration, anti-religious propaganda, increase in taxes, arrests of priests and so on. As a result of that policy, churches became absolutely illegal by the end of the 30s. The period of the New Economic Policy can be regarded as the period of temporary balance of forces when the government had to at least pretend to reckon with the fact of religious beliefs of the USSR citizens. By 1928 that delicate balance was ruined and religion was prohibited. Russia embarked on their grandiose plans to build the socialistic republic. Not only traditional economic relations, but also the style of life and thinking and the peasant's religious ideology were meant to be eliminated. Religious ideology was quite a serious threat to the new faith, communism. Thus, the period since 1929 till 1943 was the time of the most intensive repressions of the communities of Evangelical Christians and Baptists in Bashkiria. The governmental tried to eliminate religious communicated by creating negative legal conditions for them. As a result of that policy, all activities performed by religious communities became illegal and the number of such communities was reduced to a minimum. Only the Great Patriotic War stopped the process.

Ключевые слова: История, Советское государство, религия, религиозная политика, методы, баптизм, христианство, ичерковь, борьба, пропаганда

Keywords: history, Soviet state, religion, religious policy, methods, Baptism, Christianity, church, fight, propaganda. 
$\Pi$ ериод нэпа можно считать периодом временного равновесия сил, когда власти еще были вынуждены хотя бы внешне считаться с фактом религиозности населения СССР. К 1928 г. это шаткое равновесие заканчивается и начинается широкомасштабное наступление на веру и верующих. Страна приступает к осуществлению грандиозных планов социалистического строительства. В области внутренней политики все было нацелено на раскрестьянивание деревни и слом не только традиционного хозяйственного уклада, но и образа жизни, мышления, крестьянской религиозной идеологии. Религиозная идеология составляла серьезную конкуренцию насаждаемой новой вере коммунизму ${ }^{1}$.

В мае 1927 г. на Всесоюзном совещании Агитпропа религиозные организации были названы единственными легально существующими буржуазными организациями в СССР. Религия все более представлялась властям враждебной силой, с которой надо бороться как с классовым врагом до полного уничтожения. Ее начинают рассматривать исключительно как орудие классового угнетения. Религиозные организации объявляются проводниками буржуазного влияния, которые будто бы мобилизуют реакционные и малосознательные элементы страны в целях контрнаступления на мероприятия советской власти и большевистской партии. Все чаще звучат утверждения, что духовенство принимает активное участие в антисоветской работе кулачества, агитируя против сдачи хлеба заготовительным органам, и срывает мероприятия по коллективизации и социалистическому переустройству сельского хозяйства.

Основным юридическим документом, определяющим новые реалии, стал указ Президиума ВЦИК «О религиозных объединениях» от 8 апреля 1929 г. Он существенно ущемлял права религиозных организаций по сравнению с декретом 1918 г., ставя религиозные организации под контроль государства и запретив различные формы взаимопомощи, совместные молитвы, чтение Писания и т.д. Вся деятельность церкви ограничивалась совершением религиозных обрядов.

Эти требования сыграли роковую роль в истории баптистских общин Башкирии. Особенность религиозной практики баптизма заключается в не-

${ }^{1}$ Юнусова А.Б. Ислам в Башкортостане. - Уфа, 1999- С.147. большой роли формализованных обрядов. Большое значение придается совместному общению в молитве и исследовании Писания. «Мы веруем, что Бог утвердил благодатные средства, которыми он привлекает к Себе грешников и усвояет им спасение, приобретенное Христом. Относительно их Бог установил определенный порядок, который не может быть изменен нами без нарушения Божественной воли. Средства эти следующие: a) Слово Божие. Обращенные через него действием Святого Духа присоединяются к Церкви Христовой через б) крещение, и члены этой церкви совершают в ней в) святую вечерю для возвещения смерти Христовой и для теснейшего общения с Ним. В святой Вечере в то же время г) общение святых находит свое высочайшее выражение. Однако д) молитва есть душа всех этих средств и благодатного состояния вообще, она начинается с первого момента новой жизни и никогда уже не прекращается» ${ }^{2}$. Запретить проводить специальные молитвенные собрания, собрания по изучению вероучения, формы взаимовыручки и материальной поддержки означало парализовать деятельность баптистских общин и свести ее к формальному исполнению обрядовых традиций.

Решением XIV Всероссийского Съезда Советов в мае 1929 г. была изменена статья 4 Конституции РСФСР. Вместо признававшейся за гражданами «свободы религиозной и антирелигиозной пропаганды», теперь статья 4 гарантировала «свободу религиозных исповеданий и антирелигиозной пропаганды». Нетрудно представить, что это означало для евангельских конфессий, для которых подлинная вера непременно включает труд благовестия ${ }^{3}$.

Одновременно с ужесточением законодательства начался сильный нажим на конфессиональные структуры евангельских союзов. В 1929 г. прекратили существование региональные союзы баптистов (Башкирские общины входили в Волго-Камский союз баптистов). Был остановлен выпуск печатных изданий: журналов «Христианин» (1928 г.), «Баптист» (1929 г.). Перестали функционировать Библейские курсы.

Союз баптистов был закрыт в 1929 г. В 1930 г. в сильно ограниченном варианте его деятельность

\footnotetext{
${ }^{2}$ История баптизма: сборник. Вып. 1. - Одесса, 1996. - С.425.

${ }^{3}$ Митрохин Л.Н. Баптизм: история и современность (фило-
} софско-социологические очерки), - СПб., 1997.- С.390. 


\section{Политика и общество 1 (109) • 2014}

возобновилась. Весь процесс сопровождался арестами одного за другим принципиальных лидеров и основателей союза: П.В. Иванова-Клышникова, М.Д. Тимошенко, Н.В. Одинцова, П.Я. Дацко. Приходившие им на смену молодые служители, по свидетельству Г.П. Винс (отец которого Петр Яковлевич, один из лидеров Дальневосточного союза баптистов был участником событий тех лет), чаще всего были ставленниками ГПУ. ${ }^{4}$ Однако их сотрудничество с властью не спасло Союз баптистов. В 1935 г. он прекратил деятельность окончательно.

Похожая судьба была и у Союза евангельских христиан. Его деятельность была приостановлена в 1930 г. После заверений о покорности власти удалось возобновить его деятельность в 1931 г. Полностью подотчетный властям, он продолжал номинальное существование до самого образования ВСЕХБ в 1944 г.

Повсеместно по всей стране началось снятие с регистрации общин и аресты руководителей. В октябре 1929 г. вышло постановление № 329 НКВД РСФСР «О регистрации религиозных объединений», согласно которому все религиозные объединения, не прошедшие перерегистрацию до 1 мая 1930 г., считались закрытыми. Порядок регистрации был определен инструкцией № 328 НКВД «О правах и обязанностях религиозных объединений» от того же числа. Отчетность составлялась в соответствии с постановлением № 77 НКВД РСФСР от 6 декабря 1929 г. В Башкирии действовало постановление НКВД БАССР от 25 декабря 1929 года ${ }^{5}$.

Еще в феврале 1929 г. исполняющий обязанности наркома внутренних дел БАССР Стенин разослал начальникам административных отделов кантонов республики циркулярное письмо. В нем говорилось: «Несмотря на 10 лет существования Советской власти, мы до сих пор не имеем точного учета сектантства в Башкирии. Между тем мы знаем, некоторые секты носят явно антисоветский уклон и ведут свою работу без учета со стороны власти.... Приказываю:

1) В месячный срок провести точный переучет всех сект, причем после истечения данного срока все секты, которые уклонились от переучета, считать как нелегально существующие организации и

\footnotetext{
${ }^{4}$ Винс Г.П. Тропою верности. 1997. - С 50.

5 Действующее законодательство о религиозных объединениях. - Уфа, 1930. - С.43-44.
}

применять к ним меры согласно существующему закону как к нелегальным организациям;

2) При перерегистрации необходимо от всех требовать протокол постановления общего собрания о признании ими службы в Красной Армии с оружием в руках. В случае отказа той или иной секты от предоставления желаемого протокола секты не регистрировать и считать распущенными, о чем объявить под расписку руководителям сект...» ${ }^{6}$.

На основании этого письма началось сокращение числа зарегистрированных общин евангельских христиан и баптистов. Достоверно неизвестно, сколько раз власти устраивали подобные переучеты. Известно, что Скимская община вновь была зарегистрирована 7 января 1931 г. ${ }^{7}$ Решением БашЦИК от 31 мая 1937 г. молитвенный дом общины закрыт и передан под школу.

Бирская община потеряла регистрацию в 1927 г. и не имела ее до 1973 г. Какое-то время продолжались собрания. С 1930 г. деятельность общины была фактически парализована ${ }^{8}$. Активность выражалась только в том, что пресвитер общины Ф.А. Алексеев время от времени навещал семьи верующих ${ }^{9}$.

Уфимская община лишилась регистрации в 1929 г. В начале 30-х годов община была перерегистрирована. В 1935 г. закрылась окончательно.

Шаровская община лишилась регистрации в 1929 г. Вновь было подано заявление на регистрацию 30 сентября 1934 года ${ }^{10}$.

Серьезность намерений государства в отношении религиозных организаций в 30-е гг. подтверждается тем, что постановлением ВЦИК была образована Центральная комиссия по рассмотрению религиозных вопросов с сетью местных отделений. На комиссии при областных ЦИК возлагалось «наблюдение за правильным проведением на местах законов, связанных с культами, рассмотрение дел о закрытии молитвенных зданий, рассмотрение жалоб и обращений», или, по-другому говоря, координация действий государственных органов в отношении религиозных культов ${ }^{11}$. Комиссия при

\footnotetext{
${ }^{6}$ ЦГИА РБ. Ф. И-394. Оп. 9. Д. 42. Л.66.

${ }^{7}$ Там же. Оп. 2. Д. 2078. Л.51.

${ }^{8}$ Архив УФСБ РФ по РБ. ВФ 11858. Т.1. Л.95,96.

${ }^{9}$ Там же. ВФ 5175. Т.1. Л.110.

${ }^{10}$ ЦГИА РБ. Ф. Р-1230. Оп. 3. Д. 44. Л.10.

${ }^{11}$ ЦГИА РБ. Ф. Р-394. Оп. 2. Д. 2080. Л.14-17.
} 
Президиуме БашЦИК по вопросам культов была создана 23 июля 1931 года ${ }^{12}$. Эта комиссия стала основной структурой, ответственной за закрытие молитвенных зданий. Как правило, закрытие происходило «по просьбам трудящихся». За один день заседаний принимались решения о закрытии 612 молитвенных зданий разных вероисповеданий. Всего в ЦГИА РБ находится около 1000 дел о закрытии культовых зданий по всем районам Башкирии в указанный период ${ }^{13}$. Во второй половине $30-$ хг. были закрыты все молитвенные здания баптистов и евангельских христиан и почти все мечети и церкви на территории БАССР.

В 1928-1929 гг. происходит усиление практически бездействовавшего до того времени Союза воинствующих безбожников. В декабре 1928 г. в Уфе проведен областной Съезд безбожников. Увеличена сеть ячеек СВБ. Если в 1927-1928 гг. их было 120 с 7120 членами, то в 1929 г. стало 401 с 13500 членами союза безбожников ${ }^{14}$. Одной из задач республиканской организации СВБ было объявлено «изучение деятельности сектантов» ${ }^{15}$.

В июле 1929 г. прошел II Всесоюзный Съезд воинствующих безбожников, на котором баптисты, евангельские христиане, адвентисты и методисты прямо зачислялись в разряд религиозных организаций, верхушка которых является «политической агентурой... военно-шпионских организаций международной буржуазии». ${ }^{16}$

Было сильно ужесточено правовое положение служителей культа. Усилено налоговое бремя (подоходный налог, обязательные поставки мяса, молока, картофеля по нормам кулацких и единоличных хозяйств), служители культа привлекались к обязательным повинностям (лесозаготовки). 26 февраля 1931 г. Скимская община ходатайствовала перед Башкирским ЦИК о смягчении положения пресвитера Авотина Петра Оттовича. «Просим перевести на другие работы Авотина Петра Оттовича, руководящего нашей общиной, который является как единый

\footnotetext{
12 Там же. Д. 2337. Л.20.

${ }^{13}$ Юнусова А.Б. Указ.соч. - С.190.

${ }^{14}$ ЦГИА РБ. Ф. Р-394. Оп. 8. Д. 117. Л. 198.

${ }^{15}$ Там же. Оп. 7. Д. 7. Л.234.

${ }^{16}$ Мицкевич А.И. История евангельских христиан - баптистов. - М., 2007. - С.281.
}

служитель названной выше общины, исполняющий наши религиозные духовные требования. Но в теперешнее время вызван на основании приказа Военного Комиссариата БашАССР от 21 января 1931 г. под № 2 на лесозаготовительные работы в Белорецкий горнозаводской район, потому что он, родившись в 1905 г., и как служитель культа лишен права избирательного голоса. Но в нашей общине имеется 100 членов совершеннолетнего возраста, которые нуждаются в духовном обслуживании и которые нравственно тяжко страдают без него. И потому покорно просим БашЦИК дать распоряжение перевести Авотина Петра Оттовича на местные районные работы, чтобы он мог помимо физической работы исполнять религиозные духовные нужды» ${ }^{17}$.

СлужительевангельскогохристианстваГ.П.Винс приводит воспоминания матери о том, что означало быть «лишенцем» в начале $30-х$ гг.: «Служителей церкви власти именовали служителями культа и подвергали их, а также их семьи многим лишениям в части работы, места проживания и даже приобретения продуктов питания, так как в стране была карточная система. «Лишенцы» были лишены каких-либо гражданских прав и обречены фактически на уничтожение» ${ }^{18}$.

Несмотря на то, что жесткие правовые условия жизни верующих сохранялись все десятилетие, некоторые периоды отличались особым накалом антирелигиозной борьбы: 1) 1929-1931гг.; 2) 1937-1938 гг. В основном они определялись общим ходом развития политического режима И.В. Сталина.

Период 1929-1931 гг. стал временем репрессий вследствие активно проводившейся тогда индустриализации промышленности и особенно - советизации деревни, сопровождавшейся раскулачиванием.

В 1933-1935 гг. на короткое время происходит некоторое смягчение государственной политики. Некогда закрытые общины вновь смогли зарегистрироваться.

Пиком жестокости сталинской политики по праву считаются 1937-1938 гг. - время массовых репрессий против партийно-хозяйственных, военных, научных деятелей.

\footnotetext{
${ }^{17}$ ЦГИА РБ. Р-1252. Д. 345. Л.15.

${ }^{18}$ Винс Г.П. Указ. соч. - С.81.
} 


\section{Политика и общество 1 (109) • 2014}

На февральско-мартовском Пленуме ЦК ВКП (б) в 1937 г. прозвучал тезис И.В. Сталина об обострении классовой борьбы по мере продвижения к социализму. Он открыл простор для произвола и беззакония. В национальных республиках он, прежде всего, обернулся репрессиями против носителей «местного буржуазного национализма». Так было в Башкирской АССР. Закономерно, что в эти периоды объектом приложения сил репрессивных органов становятся и религиозные деятели. Специальный механизм репрессий уже существовал и действовал безостановочно: особое Совещание при НКВД в центре, «тройки», «двойки»на местах.

30 июля 1937 г. был издан оперативный приказ НКВД СССР № 00447 «Об операции по репрессированию бывших кулаков, уголовников и других антисоветских элементов». В нем было сказано: «Материалами следствия по делам антисоветских формирований установлено, что в деревне осело значительное количество бывших кулаков, ранее репрессированных, скрывавшихся от репрессий, бежавших из лагерей, ссылки, трудпоселков. Осело много в прошлом репрессированных церковников и сектантов, бывших активных участников антисоветских вооруженных выступлений...

Перед органами государственной безопасности стоит задача - самым беспощадным образом разгромить всю эту банду антисоветских элементов, защитить трудящийся советский народ от контрреволюционных происков и, наконец, раз и навсегда покончить с их подлой подрывной работой против основ советского государства...» ${ }^{19}$. Этот документ заложил основание самой масштабной репрессивной операции в истории России.

Прекращение легальной деятельности общин не означало исчезновения баптизма вообще. Его существование продолжилось на более глубоком «подпольном» уровне. Миграция верующих происходила не только из Башкирии, но и в Башкирию. Так, во второй половине 30 -х годов из числа мигрантов происходит формирование общины в городе Стерлитамаке. С 1936 г. там проживала вместе с детьми Павлина Рейновна Рамнек, бывший член разгромленной Скимской общины баптистов. Она приняла баптизм в 1921 г. Ее муж,

19 Ирошников М.П. Ваксер А.3. Россия в ХХ веке: народ, власть, войны, революции, общество. - СПб., 2005. - С.305. умерший в 1934 г., Ян Юрьевич Рамнек был членом Совета и проповедником Скимской общины баптистов ${ }^{20}$. В 1938 г. в Стерлитамак прибыла из Средней Азии семья Силко во главе с Родионом Евсеевичем Силко, бывшим ранее дьяконом общины города Чимкента. В 1940 г., также из Средней Азии, в Стерлитамак переселилась семья Шардаковых. Независимо от них, с 1938 г. в Стерлитамаке проживал пресвитер Рудаков Андрей Егорович. Он и стал в 1942 г. первым пресвитером нелегальной общины евангельских христиан города Стерлитамака ${ }^{21}$. В 40-е годы эта община станет одной из крупнейших в Башкирии.

Таким образом, период с 1929 по 1943 г. был временем самого активного репрессивного воздействия на общины евангельских христиан и баптистов Башкирии. Правительство проводило политику уничтожения общин верующих, которые были поставлены в крайне неблагоприятные правовые условия. Итогом политики стало прекращение легальной деятельности всех общин верующих и сведение их численности до минимума. Начатый процесс приостановила только начавшаяся Великая Отечественная война.

\section{Библиография:}

1. Юнусова А.Б. Ислам в Башкортостане. - Уфа, 1999-C.147.

2. История баптизма: сборник. Вып. 1.-Одесса, 1996.-C.425.

3. Митрохин Л.Н. Баптизм: история и современность (философско-социологические очерки). СПб., 1997.-С.390.

4. Винс Г.П. Тропою верности. 1997.-С 50.

5. Действующее законодательство о религиозных объединениях.-Уфа, 1930.-С.43-44.

6. ЦЦИА РБ. Ф. И-394. Оп. 9. Д. 42. Л.66.

7. ЦЦГИА РБ. Ф. И-394. Оп. 2. Д. 2078. Л.51.

8. Архив УФСБ РФ по РБ. ВФ 11858. Т.1. Л.95,96.

9. Архив УФСБ РФ по РБ. ВФ 5175. Т.1. Л.110.

10. ЦГИА РБ. Ф. Р-1230. Оп. 3. Д. 44. Л.10.

11. ЦГИА РБ. Ф. Р-394. Оп. 2. Д. 2080. Л.14-17.

12. ЦГИА РБ. Ф. Р-394. Оп. 2. Д. 2337. Л.20.

\footnotetext{
${ }^{20}$ ЦГИА РБ. Р-251. Оп. 2. Д. 131. Л.41-42.

${ }^{21}$ История евангельских христиан г. Стерлитамака. Руко-
} пись. - С. 11 . 
13. Юнусова А.Б. Указ.соч.-С.190.

14. ЦГИА РБ. Ф. Р-394. Оп. 8. Д. 117. Л. 198.

15. ЦГИА РБ. Ф. Р-394. Оп. 7. Д. 7. Л.234.

16. Мицкевич А.И. История евангельских христианбаптистов. - М., 2007.-С.281.

17. ЦГИА РБ. Р-1252. Д. 345. Л.15.

18. Ирошников М.П. Ваксер А.З. Россия в XX веке: народ, власть, войны, революции, общество. СПб., 2005.-С.305.

19. ЦГИА РБ. Р-251. Оп. 2. Д. 131. Л.41-42.

20. История евангельских христиан г. Стерлитамака. Рукопись. - С.11.

\section{References (transliteration):}

1. Yunusova A.B. Islam v Bashkortostane. - Ufa, 1999 - S.147.

2. Mitrokhin L.N. Baptizm: istoriya i sovremennost' (filosofsko-sotsiologicheskie ocherki). - SPb., 1997. - S.390.

3. Vins G.P. Tropoyu vernosti. 1997.-S 50.

4. Yunusova A.B. Ukaz.soch.-S.190.

5. Iroshnikov M.P. Vakser A.Z. Rossiya v KhKh veke: narod, vlast', voiny, revolyutsii, obshchestvo. - SPb., 2005. - S.305. 